\title{
SPECIAL REQUIREMENTS FOR CORPORATE COMMUNICATIONS IN GEOGRAPHICALLY DEFINED MARKETS USING THE EXAMPLE OF THE SALE OF CONSTRUCTION FINANCING IN RURAL AREAS
}

\author{
Christian Enz ${ }^{1}$
}

Received: March 31, 2019 / Revised: July 10, 2019/ Accepted: October 10, 2019

(C) Association of Economists and Managers of the Balkans, 2019

\begin{abstract}
Private mortgage lending business is an important business segment for retail banks. There are two main reasons for this. Firstly, the comparatively low risk. On the one hand, because many years of experience in this segment enable optimal risk management. On the other hand, the financed properties also provide optimum security. Due to the small size of this business segment, private construction financing was unattractive for major banks for a long time. On the other hand, this division was a core business for regional banks and savings banks. However, as a result of the banking crisis in 2007 and 2008 and the ECB's ongoing low-interest policy, the private mortgage lending sector is now attractive to all market participants. This is reflected in fiercer competition. The importance of customer communication has therefore also increased in the advertising for new business. Since financial and personnel resources are limited, corporate communications are faced with the challenge of addressing potential customers as efficiently as possible. Communication science has already developed a number of concepts for optimal, integrated communication. These are based on average consumers. Against the background of possible regional deviations in media usage and consumer behaviour, this work explains that banks and savings banks with a regionally defined business area should set different priorities within the communications mix than supraregional providers. To this end, a field study was conducted in rural areas of the Nuremberg metropolitan region and analysed using a chi-square test. The study revealed the continuing importance of branches and personal advice, despite increasing digitalisation. At the same time, the necessity of closely networking stationary sales and online offers in rural areas becomes clear.
\end{abstract}

Keywords: SME, Integrated Communication, Communication Mix, Retail, Bank, Savings Bank, Construction Financing, Sales, Competition, Regional Economic Areas.

JEL Classification M310 $\cdot$ M370 $\cdot$ R110

This paper was presented at the Fifth International Scientific Conference on Knowledge Based Sustainable Development - ERAZ 2019 - May 23, Budapest, Hungary, www.eraz.org.rs

Christian Enz

enzchr00@jcu.cz

1 University of South Bohemia, Faculty of Economics, Studentská 13, CZ-37005 Ceské Budejovice, Czechia 


\section{INTRODUCTION}

In the meantime, major banks are turning to the small-scale lending business, which had previously been handled predominantly by regional banks and savings banks. (Kübler \& Weiss, 2012) At the same time, FinTechs or online comparison portals are creating new market participants. (Durst \& Durst, 2016) In addition, the continuing low interest rate policy is having a strongly limiting effect on the earnings side of financial institutions. (Dombret, 2017) Regional banks are increasingly under competitive pressure. A development that can also be observed in other sectors. (Škodová Parmová, Líšková \& Kain, 2018) The reason for this is the economic and social environment in which companies operate today. This is increasingly characterised by complexity, dynamism (Škodová Parmová, Líšková, Sdrolias \& Kain, 2017) and finally competition. Small and medium-sized enterprises in particular run the risk of being forced out of the market by large companies. (North, 2007) They face the challenge of optimising their processes and increasing their own competitiveness (Eßer, Messner \& Meyer-Stamer, 1990; (Škodová Parmová, Líšková \& Kain, 2018).

Particular importance is attached to marketing communication in view of the increasing intensity of competition. Because only if the right approach to demanders is successful can necessary sales targets can be achieved. A variety of approaches already exists. (Balmer \& Greyser, 2003; Bruhn \& Strauss, 2000; Valackiene, 2010) These are aimed at addressing the average statistical customer. The question is whether the success of a communication mix developed for supraregional markets can be transferred without loss of effectiveness to providers with a regionally limited business area. The aim of this research paper is to clarify this question using the example of regional banks and savings banks.

\section{THEORETICAL BACKGROUND}

The aim of this research project is to enable regional providers, especially SME, to assess the necessity of adapting communication models. It can be assumed that there is a need for adaptation, since according to Buchner (Buchner, 1998) established approaches for an efficient communication mix are oriented towards a statistical average consumer. Although people are unique in their behavior. (Wölki, 2007)

\subsection{Communication mix}

The task of communication policy is influencing the decisions of target group members in the interests of the company. (Klewes, 2005; Bruh, 2010; Ternés, Jerusel \& Schmidtbleicher, 2017) This goal can be achieved through the use of various instruments. This is why the model of the communication mix has evolved. (Melzer, 2015)

\subsection{Average customer}

The average customer is a central component of market segmentation. A large number of segmentation approaches already exist for this purpose. (Meffert, Burmann \& Kirchgeorg, 2012) These take into account demographic characteristics such as age or income (Feigl, 2015) as well as geographical, sociological or psychographic criteria. (Freter, 2008)

\subsection{Media impact}

Consumption presupposes the previous establishment of contact between supplier and consumer. Thus, a purchase is always preceded by an interaction. (Bruhn \& Strauss, 2000) Media effectiveness is given when an action is intended by addressing via a certain channel. According to Sander, 
the quantitative survey of consumers is the ideal instrument for gaining insights into their behaviour and the effectiveness of previous communication. (Sander, 2017) Others (Lindner, 2015) confirms this, especially with regard to the evaluation of behaviour patterns. The research project presented here is based on the following hypotheses to be verified:

Hypothesis 1: The effect of a communication channel is not dependent on the regional affiliation of a recipient.

Hypothesis 2: The regional dependence of the effect of a communication channel has not changed significantly due to technical progress.

\section{DATA AND METHODS}

This paper examines whether the impact of certain communication channels in rural areas differs from that at national level. In addition, it is tested whether a possible deviation changes significantly over time.

\subsection{Large number investigation}

In order for the results to serve the management of small and medium-sized enterprises later as a basis for decision-making, a precise description is necessary. It must be possible to clearly identify the type of region to which the findings apply by means of comprehensible factors (Foran \& Lebel, 2012; Škodová Parmová, Líšková \& Kain, 2018). Due to limited resources, it is not possible to interview all residents. A sample was carried out to obtain primary data. The media impact on inhabitants of municipalities with less than 16,000 inhabitants who have acquired their own homes within the last ten years was investigated. In order to reach this group of people, a targeted distribution of questionnaires was carried out in corresponding building areas.

\subsection{Survey}

A questionnaire was developed to survey the media impact. In order to ensure the best possible participation, the questionnaire was limited to the two questions necessary to answer the hypotheses. Both questions could only be answered with a single selection.

Question 1: Where did you conclude your construction financing? The answer to this question was available: Principal bank (here a salary account was already kept before the construction financing), Branch bank, Internet bank, property developer and Real estate sales associate.

Question 2: How did you first become aware of the provider of your mortgage? Here were the possible answers: Already a customer there, Internet, TV, Radio, Newspaper, active approach of the provider, recommendation by friends/acquaintances.

\subsection{Analysis}

Since only nominal-scaled data are used, contingency analysis can be used to check correlations. (Leibinger \& Sander, 2017) Statistically, a dependency exists if the distribution of one observed variable does not match for all characteristics of the other observed variable. (Kähler, 2011) The $\mathrm{Chi}^{2}$ test according to Pearson can be used for this purpose. (Hladik, Kubecka, Mrkvicka et. Al, 
2008; Leibinger \& Sander, 2017) If the expected frequency in more than 20 percent of the cells is less than 5, the analysis is carried out with the exact Fisher test. The same happens if the expected frequency is less than 1. (Universität Zürich, 2017)

\section{RESULTS}

The first step is to check whether there is any dependency at all between the communication channel and the selected provider. For this purpose, the values from the 2013 survey are recorded in a table. Then the values from the year 2018, followed by an analysis using an exact Fisher test. Both calculations lead to a p-value smaller than the significance level alpha $=0.05$. The null hypothesis „There is no dependency" must therefore be rejected. It has thus been demonstrated that in 2013 and 2018 there will be dependencies between the choice of provider and the communication channel used for buyers of a construction loan.

This research work is based on a repeated survey. The sample from 2013 contains 71 completed questionnaires (2013: $\mathrm{n}=71$ ). The repeat question in the same geographical area was answered by 94 persons (2018: $\mathrm{n}=94$ ). To survey the sample, 2,000 questionnaires were distributed in the target area.

The importance of the individual communication channels is of interest for this research project. These will be compared with their supra-regional importance.

Table 1. Communication channel/purchase decision

\begin{tabular}{|c|c|c|c|c|c|}
\cline { 2 - 6 } \multicolumn{1}{c|}{} & Principal bank & Branch bank & Internet bank & $\begin{array}{c}\text { Property } \\
\text { developers }\end{array}$ & $\begin{array}{c}\text { Real estate } \\
\text { sales associate }\end{array}$ \\
\hline $\begin{array}{c}\text { Already } \\
\text { customer }\end{array}$ & $-8,81 \%$ & $5,56 \%$ & $0,00 \%$ & $0,00 \%$ & $0,00 \%$ \\
\hline Internet & $6,56 \%$ & $16,67 \%$ & $16,67 \%$ & $0,00 \%$ & $0,00 \%$ \\
\hline TV & $3,28 \%$ & $-11,11 \%$ & $20,83 \%$ & $0,00 \%$ & $0,00 \%$ \\
\hline Radio & $0,76 \%$ & $0,00 \%$ & $-25,00 \%$ & $0,00 \%$ & $20,00 \%$ \\
\hline Newspaper & $0,00 \%$ & $-5,55 \%$ & $0,00 \%$ & $0,00 \%$ & $0,00 \%$ \\
\hline Active address & $0,00 \%$ & $5,56 \%$ & $0,00 \%$ & $-75,00 \%$ & $-30,00 \%$ \\
\hline Referral & $-1,77 \%$ & $-11,11 \%$ & $-12,50 \%$ & $75,00 \%$ & $10,00 \%$ \\
\hline
\end{tabular}

These measured changes are offset by a behavior in marketing communication that is shown in Table 2. It shows the market shares of the media in advertising in Germany. In other words, the reference value for the sample carried out in one region of Germany. In the period under review, this was characterised by an increase in activities in the Internet $(+6 \%)$, TV $(+6 \%)$ and a sharp reduction in activities in the newspaper sector $(-5 \%)$.

Table 2. Market shares of the media in advertising until 2017 (ZAW Zentralverband der deutschen Werbewirtschaft e.V., 2018)

\begin{tabular}{|c|c|c|c|c|}
\cline { 2 - 5 } \multicolumn{1}{c|}{} & Internet & TV & Radio & Newspaper \\
\hline $\mathbf{2 0 1 3}$ & $8 \%$ & $27 \%$ & $5 \%$ & $42 \%$ \\
\hline $\mathbf{2 0 1 4}$ & $9 \%$ & $28 \%$ & $5 \%$ & $40 \%$ \\
\hline $\mathbf{2 0 1 5}$ & $9 \%$ & $29 \%$ & $5 \%$ & $38 \%$ \\
\hline $\mathbf{2 0 1 6}$ & $10 \%$ & $30 \%$ & $5 \%$ & $37 \%$ \\
\hline $\mathbf{2 0 1 7}$ & $11 \%$ & $30 \%$ & $5 \%$ & $36 \%$ \\
\hline
\end{tabular}


The communication channels „Already customer” and „Active approach” cannot be represented in media view. The operation of a branch network is regarded as representative of this type of communication in the sense of this research work. This is based on the assumption that the number of bank branches has an effect on direct customer contact. In Germany, the number of banking outlets fell from 38,225 in 2015 to 31,949 (Deutsche Bundesbank, 2018) in 2017. Direct contact can also be made within the framework of dialogue marketing campaigns. Against this background, the development of expenditure on dialogue marketing in Germany must also be taken into account here. In the period under review, these increased by EUR 1 billion from EUR 17.8 billion (2013) to EUR 18.8 billion in 2017. (Deutsche Post AG, 2018)

\section{DISCUSSION}

The analysis of the response behaviour of the target group provides an initial insight. In the 2018 repeat survey, only $32.98 \%$ of respondents used the postal service. The far larger proportion $(67.02 \%)$ chose the Internet to answer the questions. This shows that technical progress and the associated global trend towards more e-business (Kulyk \& Škodová Parmová, 2017) has now also made considerable progress in rural regions of Germany.

Nevertheless, the majority of the 2018 respondents $(90.43 \%)$ decided to take out a mortgage with a branch bank. This figure is even 10\% higher than the rate of $80.28 \%$ determined in the first survey in 2013. This means that the importance of the branch as a sales channel for mortgage lending in the target region in question has risen against the trend.

However, technological developments are changing the way business is conducted (Kulyk \& Škodová Parmová, 2017). Thus, the importance of the branch as a communication channel intending to act decreased. In this way, the repeat survey identified $3.25 \%$ fewer deals than five years ago.

In the five-year period under consideration, the communication channel Internet gained the most importance. In the repeat survey, it initiated $39.90 \%$ more deals than in 2013 . At $16.67 \%$, the increase in the Internet banking category was just as significant as for branch banks. Customers who took out mortgages with their principal bank were also increasingly motivated via the Internet. A plus of $6.56 \%$ can be identified here. The importance of this communication channel is therefore growing faster than advertising budgets at this point. For the period under review, these only show a plus of $3 \%$.

Advertising commitment on TV was also increased by $3 \%$ in the period under review. This, in turn, is clearly below the measurable significance. In 2018, an increase of $13.00 \%$ was recorded across all types of contracts.

The present research project thus shows that there are differences between the regionally measured initial effect of a communication channel and its supraregional significance.

In order to clarify Hypothesis 1, it is necessary to examine the significance of these deviations. For this purpose, the regionally determined frequencies are compared with a supraregionally determined expected value. As part of a secondary data analysis, the values from a survey conducted by Deloitte in 2010 are used for this purpose. Since the calculated p-value is smaller than the significance level alpha $=0.05$, the null hypothesis $\mathrm{H} 0$ must be rejected. The alternative hypothesis Ha must be accepted. This hypothesis states that the effect of a communication channel in 2013 depends on the regional affiliation of a recipient. The same evaluation then takes place with the data from 2018 - and comes to the same result. 
Hypothesis 2 states that the regional dependence of the effect of a communication channel has not changed as a result of technological progress. This statement is now also verified in a final step. For this purpose, the results of the samples from 2013 and 2018 are tested for significance in a chi-square test. The basis is the average observed values per communication channel. Since the calculated p-value of 0.046 is lower than the significance level alpha $=0.05$, the null hypothesis $\mathrm{H} 0$ must be rejected and the alternative hypothesis Ha accepted. It follows from this that technical progress has an impact on the opinion-forming power of the individual communication channels.

\section{CONCLUSION}

The management fields of marketing and communication are characterised by progressive professionalisation (Niebergall \& Röttger, 2018; Röttger, Kobusch \& Preusse, 2018). This is due to major changes in the opinion-forming and information procurement processes of target groups over the past ten years. This requires a faster and more accurate approach. It is also no longer enough simply to send out messages. To control the flow of information, bilateral communication between companies and recipients is necessary (Sdrolias, Kakkos, Škodová Parmová, et. al, 2016). In addition to traditional instruments, PR, marketing and sales also use new communication channels to gain attention or relevance for their communicative messages (Lommatzsch, 2018). These have remained the main concerns of institutional communication. (Sdrolias, Kakkos, Škodová Parmová, et. al, 2016)

Efficiency has a high priority in the choice of instruments and the distribution of budgets. Companies worldwide therefore invest an average of 6.7 percent of their marketing budgets in modern analysis methods. It seems that the demonstrably better performance as the main reason for this (Perrey, 2018).

However, data-driven marketing planning requires a valid database (Staudacher, 2018). In practice, however, there is often a lack of valid data. Others complains that $45 \%$ of companies have only incomplete customer data, which is why secondary data is used (Kreutzer \& Land, 2017). Planning on the basis of secondary data may have proved successful for supraregional providers. The present research work, however, proves that geographically defined regions can deviate significantly from national or international average behaviour in terms of media use. Against this background, communication concepts oriented towards the average customer must be critically questioned.

The present research work shows that in rural areas the traditional communication channels of branch offices, newspapers and personal contact by the consultant still have a significant influence on the probability of a mortgage being concluded.

It also becomes clear that the Internet is becoming increasingly important in the process of forming opinions and building customer loyalty. At the same time, people are looking for a personal contact person and physical proximity at the end of the day, at least in the case of transactions that require explanation, such as the conclusion of a construction loan. Against this background, the steady reduction of bank branches with reference to increasingly used online banking services must be critically questioned. Banks and savings banks are following numerous other sectors with their strategy of using the ongoing digitalisation to reduce costs. Staudacher (2018) deplores this development as it does not lead to improved customer orientation. At the same time, however, it has a negative impact on existing customer relationships (Hinterberger, 2018). 
The present research work also makes it clear that the importance of different communication channels in the process of forming opinions varies from region to region. This confirms the tendency to meet the growing global challenges with their own regional strategies (Škodová Parmová, Líšková \& Kain, 2018).

On the other hand, it does not provide a reliable statement on which communication channels are particularly important in rural areas. The random samples in the number of cases were too small for this. Also not investigated was the question of whether only the rural area in West-Middle Franconia analysed in the research project deviates from the average customer - or whether deviations are to be expected in all rural areas. Also not considered is the question of whether there are deviations only in rural areas or also in metropolises. Thus, the present research work is at the same time an impetus for further research in these directions.

\section{REFERENCES}

Balmer, J. \& Greyser, S. (2003). Revealing the corporation. London: Routledge.

Balmer, J. \& Greyser, S. (2006). Corporate marketing. European Journal of Marketing, 40 (7/8), 730-741.

Bruhn, M. \& Strauss, B. (2000). Dienstleistungsqualität. Wiesbaden: Gabler.

Bruhn, M. (2010). Kommunikationspolitik. Systematischer Einsatz der Kommunikation für Unternehmen. München: Vahlen.

Buchner, D. (1998). Mehr Kundennähe. Von Kunden lernen, Kunden begeistern und binden. Wiesbaden: Gabler.

Deutsche Bundesbank (2018). Anzahl der Bankstellen in Deutschland in den Jahren von 1957 bis 2017. Bankenstatistik, 6, 104

Deutsche Post AG (2018). Werbeaufwendungen im Dialogmarketing in Deutschland in den Jahren 2012 bis 2017. Dialogmarketing Deutschland, 11

Dombret, A. (2017). Die Niedrigzinspolitik der EZB - Fluch oder Segen für Wirtschaft, Verbraucher und Banken?, Wirtschaftspolitische Blätter, 2017 (4).

Durst, M. \& Durst, C. (2016). Ein Future-Management-System für das Retail-Banking der Zukunft. In Seidel, M. (Ed.), Banking \& Innovation 2016. (pp 195-206). Wiesbaden: Springer Gabler.

Eßer, K, Messner, D. \& Meyer-Stamer, J. (1990). Systemische Wettbewerbsfähigkeit: Neue Anforderungen an Unternehmen und Politik. Vierteljahreshefte zur Wirtschaftsförderung, 64 (2), 186-199.

Feigl, P. (2015). Zielgruppenbestimmung von Mietern. Wiesbaden: Springer Gabler.

Foran, T. and Lebel, L., (2012), Using holistic scenarios to rewrite rural futures. In: Measham,T. and Lockie, S. (Ed.), Risk and Social Theory in Environmental Management. (p. 199-219). Melbourne: Csiro Publishing.

Freter, H. (2008). Markt- und Kundensegmentierung. Stuttgart: Kohlhammer.

Hinterberger, M. (2018). Die Filiale vor Ort wird immer seltener, nicht nur in kleinen Dörfern. Warum die Institute ihre Geschäftsstellen dichtmachen und worauf Kunden sich künftig einstellen müssen. Börse online. Retrieved from https://www.boerse-online.de/nachrichten/geld-und-vorsorge/banken-schliessen-immer-mehr-filialen-was-kunden-wissen-muessen-1016723403

Hladik, M., Kubecka, J., Mrkvicka, T., Cech, M., Drastik, V., Frouzova, J., Hohausova, E., Matena, J., Matenova, V. Kratochvil, M., Peterka, J., Prchalova, M., Vasek, M. (2008). Effects of the construction of a reservoir on the fish assemblage in an inflow river. Czech Journal of animal science. 53 (12), 537-547 
Kähler, W. (2011). Statistische Datenanalyse. Wiesbaden: Vieweg + Teubner.

Klewes, J. (2005). Unternehmenskommunikation auf dem Prüfstand. Wiesbaden: Deutscher Universitätsverlag.

Kreutzer, R. \& Land, K. (2017). Digitale Markenführung. Wiesbaden: Springer Fachmedien.

Kübler, B. \& Weiss, R. (2012). Pro \& Contra Unternehmensbewertung. Bankvertrieb, 2012 (7), 186-199. Retrieved from https://www.springerprofessional.de/bankvertrieb/ firmenkunden/ pro-contra-unternehmensbewertung/6601584

Kulyk, V., Škodová Parmová, D. (2017). E-business Development: The Comparative Study of the Czech Republic and the Ukraine. Deturope, 9, 1: 80-110

Leibinger, T. \& Sander, Matthias. (2017). Downsizing bei Konsumgütern. Wiesbaden: Springer Fachmedien.

Lindner, A. (2015). Kundenwünsche - entwickeln, antizipieren, entsprechen. Marketing Review St. Gallen 32 (2), 20-29.

Lommatzsch, T. (2018). Begriffsklärung: Influencer Marketing vs. Influencer Relations. In Leonarz, M. (Ed.), Influencer Relations. (pp. 23-26). Wiesbaden: Springer Gabler.

Meffert, H., Burmann, C. \& Kirchgeorg, M. (2012). Marketing. Grundlagen marktorientierter Unternehmensführung. Wiesbaden: Gabler.

Melzer, D. (2015). Personal Branding und Celebrity Marketing im Profifußball. Mittweida: University of Applied Sciences Mittweida.

Niebergall, J. \& Röttger, U. (2018). Zum Zusammenhang von Professionalierungsbestrebungen des PR-Berufsfeldes und seiner Vertrauenswürdigkeit. In Hoffjann, O. \& Seidenglanz, R. (Ed.), Allmächtige PR, ohnmächtige PR (pp. 303-328). Wiesbaden: Springer Fachmedien.

North, K. (2007). Wissensorientierte Unternehmensführung in kleinen und mittleren Unternehmen. In Bellinger, A. \& Krieger, D. (Ed.), Wissensmanagement für KMU (pp. 167-186). Zürich: vdf Hochschulverlag.

Perrey, J. (2018). Marketing in neuer Dimension. In Bruhn, M. \& Kirchgeorg M. (Ed.), Marketing Weiterdenken. (pp. 257-276). Wiesbaden: Springer Gabler.

Röttger, U., Kobusch, J. \& Preusse J. (2018). Grundlagen der Public Relations. Wiesbaden: Springer VS.

Sander, M. (2017). Der Einfluss der Digitalisierung auf die Markenstrategie und das Markenerlebnis. In Theobald, E. (Ed.), Brand Evolution. (pp 197-214). Wiesbaden: Springer Gabler.

Sdrolias, L., Kakkos, N., Škodová Parmová, D., Rolinek, L., Cudlínová, E., Aspridis, G., Líšková, Z. \& Kazantzi,V. (2016). Cultural Product and Cultural Communication as a Dynamic Bipolar Interaction and Creative Contribution to the Structural Recompiled of the Local Cultural Units. In Katsoni, V. \& Stratigea, A. (Ed.), Tourism and culture in the age of innovation. (pp 41-67). Wiesbaden: Springer Proceedings in Business and Economics.

Škodová Parmová, D., Líšková, Z., Sdrolias, L., Kain, R. (2017). Systematic approaches and development strategies of the rural small and medium-sized firms in boarder regions. In Janecek, P. (Ed.), Opportunities and threats to current business management in cross-border comparison 2017. (147-155), Lobnitz: Verlag GUC - Gesellschaft Unternehmensrechnung Controlling $\mathrm{mbH}$

Škodová Parmová, D., Lišková, Z., Kain, R. (2018). Cross-border regions as supporting structures for raising competitiveness in Europe. Paper presented at $4^{\text {th }}$ International Scientific Conference ERAZ 2018. Knowledge based sustainable economic development, (pp. 65-78). Sofia: Association of Economists and Managers of the Balkans.

https://doi.org/10.31410/eraz.2018.65

Staudacher, J. (2018). Kundendaten als Einflussfaktor auf Reorganisationen in Marketing und Vertrieb. Swiss Marketing 2018, 18-20. 
Ternès, A., Jerusel, M. \& Schmidtbleicher, B. (2017). Integriertes Betriebliches Gesundheitsmanagement. Wiesbaden: Springer Gabler.

Universität Zürich (2017). Pearson Chi-Quadrat-Test (Kontingenzanalyse). Retrieved from http:// www.methodenberatung.uzh.ch/de/datenanalyse/zusammenhaenge/pearsonzush.htmh

Valackiene, A. (2010). Efficient Corporate Communication: Decisions in Crisis Management, Engineering Economics, 21 (1), 99-110.

Wölki, P. (2007). Briefing gut - Werbung gut: Marketing-Wissen für Werber, Kreative \& Co. Landsberg am Lech: mi Fachverlag, Redline GmbH

ZAW Zentralverband der deutschen Werbewirtschaft e. V. (2018). Entwicklung der Werbemarktanteile der Medien in Deutschland in den Jahren 2009 bis 2017. Werbung 2018, 12. 